\title{
Determination of Acute Lethal Doses of Acetamiprid and Cypermethrin for the Native Bee Apis mellifera (Hymenoptera: Apidae) in Cameroon
}

\author{
Sanda Mazi1,2* ${ }^{1}$, Toua Vroumsia1, Marie-Noel Yahangar1, Malloum Malla1, Dawai Zroumba1 \\ ${ }^{1}$ Laboratory of Applied Zoology, Department of Biological Sciences, Faculty of Science, University of Ngaoundéré, \\ Ngaoundéré, Cameroon \\ ${ }^{2}$ School of Geology and Mining Engineering at Meiganga, University of Ngaoundéré, Ngaoundéré, Cameroon \\ Email: *mazisanda@gmail.com
}

How to cite this paper: Mazi, S., Vroumsia, T., Yahangar, M.-N., Malla, M. and Zroumba, D. (2020) Determination of Acute Lethal Doses of Acetamiprid and Cypermethrin for the Native Bee Apis mellifera (Hymenoptera: Apidae) in Cameroon. Open Journal of Ecology, 10, 404-417.

https://doi.org/10.4236/oje.2020.107026

Received: May 13, 2020

Accepted: June 26, 2020

Published: June 29, 2020

Copyright $\odot 2020$ by author(s) and Scientific Research Publishing Inc. This work is licensed under the Creative Commons Attribution International License (CC BY 4.0).

http://creativecommons.org/licenses/by/4.0/

(c) $\underset{\mathrm{By}}{\text { (i) Open Access }}$

\begin{abstract}
Honey bees are important pollinators and are essential in agriculture; as such they get exposed to a wide range of pesticides while foraging in contaminated fields or during the spray of chemical on crops. It is therefore important to know the toxicity and evaluate the impacts of bees' exposure to these molecules. Acetamiprid and cypermethrin are two pesticides widely used in Cameroon and other countries. The objective of this study was to determine the toxicity of acetamiprid and cypermethrin on the native subspecies of Apis mellifera L. in agricultural areas in Adamaoua-Cameroon and to evaluate the impact on honeybee foragers exposed to lethal and sublethal doses of these two insecticides. The results obtained in laboratory conditions show that acetamiprid and cypermethrin are toxic to A. mellifera. The symptoms of neurotoxicity and first mortality appear $15 \mathrm{~min}$ after the ingestion of the high concentrations and about 30 to $45 \mathrm{~min}$ after the inoculation of the pesticides through contact route and the mortality increases with the concentration and time. The LC50 of acetamiprid obtained after $24 \mathrm{~h}$ are respectively $5.26 \mathrm{ng} / \mu \mathrm{l}$ for the topical application and $4.70 \mu \mathrm{g} / \mu \mathrm{l}$ by the oral route. At the same time, the LC50 of cypermethrin are respectively $2.27 \mathrm{ng} / \mu \mathrm{l}$ for topical application and $2.68 \mathrm{ng} / \mu \mathrm{l}$ for oral toxicity. For a sustainable agriculture and beekeeping, it is, therefore, important to establish quality measures on these insecticides in the ecosystem and to set up a phyto-pharmacovigilance and awareness system to the population.
\end{abstract}

\section{Keywords}

Apis mellifera, Insecticides, Acetamiprid, Cypermethrin, Toxicity 


\section{Introduction}

Over the past years, the need to feed the overgrowing population of the world was a priority and it has led to the intensification of agricultural production, transforming, by the way, many regions into a simplified landscape. This transformation has led to global degradation of the environment and therefore, the loss of biodiversity [1]. Among the threatening insects' biodiversity, are pollinators, which are inextricably linked to human well-being through the maintenance of ecosystem health and function, wild plant reproduction, crop production and food security [2]. It is therefore known that human land use is strongly linked to species richness of bees and other pollinators. However, bees are widely considered the best pollinators of crops and the most specialized flower visitors of many plant species because of their variety of morphological adaptations to collect, manipulate, transport and store pollen efficiently [3] [4].

Nearly three-quarters of the plants that produce 90 percent of the world's food require pollinators, and third of the world's food production depend on bees [2] [3] [5]. Bees are, therefore, renowned for their role in providing high-quality food, and hive products such as honey, propolis, and beeswax that are sought after by humans. They are part of the biodiversity on which we all rely on for our survival [6].

However, bees and other pollinators, are increasingly under threat from human activities. These threats include the intensification of agriculture and the use of chemical insecticides. The pesticides used in agricultural areas are persistent because they are "systemic", meaning they are dissolved and absorbed into the crop, this affects every part of the plant, from its leaves to its nectar and pollen. Insecticides are normally designed to reach insect pests, but they can also reach non-target organisms, such as honeybees which are being the most agro-environmental, and economical important insect species. These insecticides have therefore direct and indirect impacts on them [7] [8] [9].

In Cameroon in general and in the Adamaoua region in particular, no studies on the effects of insecticides on $A$. mellifera foragers have been carried out. Therefore, the objective of this work is to evaluate the effect of two insecticides, acetamiprid, and cypermethrin on $A$. mellifera in the Adamaoua region. Most specifically, it was to 1) identify the most commonly used insecticides; 2) study the impact of the most used insecticides on A. Mellifera health; 3) determine the sub-lethal toxicity of these insecticides on honeybees.

\section{Materials and Methods}

\subsection{Materials}

\section{Animal Material}

Individuals of $A$. mellifera caught from the hives of the Laboratory of applied Apidology Unit of the University of Ngaoundéré constituted our animal material.

Two insecticides bought on the Dang market constituted our chemical prod- 
ucts for bioassay: 1) Acetamiprid an insecticide of the family of neonicotinoids. It is sold in solid form with a mass concentration of $200 \mathrm{~g} / \mathrm{kg}$ under the trade name OPTIMAL and 2) cypermethrin which is an insecticide of the pyrethroid family. It is sold in liquid form with a mass concentration of $100 \mathrm{~g} / \mathrm{L}$, the trade name is CYPERCOT.

\subsection{Methods}

\subsubsection{Surveys with Farmers and Sellers}

To study the toxicity of the two most used insecticides in agricultural areas in Ngaoundéré, a survey was conducted from April to June 2018, with agrochemical products' sellers and farmers to highlight the most sold and used insecticides. 30 agrochemical sellers and 165 farmers were interviewed and data were thereafter analyzed.

\subsubsection{Experimental Design}

The purpose of the laboratory work was to determine the toxicity (LC50) of acetamiprid and cypermethrin on honeybees. For bioassay, we followed the methods of [10], methods described by [11] and [12] and those of [7] [9], and [13]. Apis mellifera workers were then caught and kept alive in cages according to [13].

\subsubsection{Capture and Conservation of Bees}

The bees were collected from the hives one day before the tests start, and were there after anesthetized by diffusion of carbon dioxide at the low flow rate, to avoid a significant drop of temperature within the boxes. After collection, groups of 20 bees were placed in wooden boxes $(10 \times 8.5 \times 6 \mathrm{~cm})$ with a side made of metal nets. Each treatment consisted of three cages of bees and was stored at $25^{\circ} \mathrm{C} \pm 2^{\circ} \mathrm{C}$. Each test was repeated three times, after each bio-assay, the bees were renewed, each test corresponding to a well-prepared dose of the insecticide.

\subsubsection{Preparation and Choice of Different Doses}

The preparation of different solutions was done by diluting volume per volume, the insecticides with drilling water. $5 \mathrm{~g}$ of OPTIMAL is dissolved in one liter of water to obtain a stock solution of $1000 \mathrm{ng} / \mu \mathrm{l}$. Similarly, a volume of $10 \mathrm{ml}$ of CYPERCOT (100 g/l) is diluted by adding $990 \mathrm{ml}$ of drilling water to obtain a stock solution of $1000 \mathrm{ng} / \mathrm{l}$. These preparations are done according to the following dilution formula:

$$
C_{i} V_{i}=C_{f} V_{f}
$$

with $C_{i}$ the initial concentration of the product, $V_{i}$ the initial volume of the product, $C_{f}$ the final concentration and $V_{f}$ the final volume of the solution to be prepared.

The choice of the different concentrations of the two insecticides was done based on the report of [14]. These diluted concentrations followed the prelimi- 
nary tests carried out with a range of 5 doses spaced by a geometric progression factor of 10 .

\subsubsection{Administration Routes of Different Treatments: Direct Route}

The bees were taken at least two hours before the test and kept at $25^{\circ} \mathrm{C}$. Inoculation of the different solutions was done by applying $1 \mu \mathrm{l}$ of the following concentration: $4.8 \mathrm{ng} / \mu \mathrm{l}, 10.65 \mathrm{ng} / \mu \mathrm{l}, 21.42 \mathrm{ng} / \mu \mathrm{l}, 51.52 \mathrm{ng} / \mu \mathrm{l}, 113.4 \mathrm{ng} / \mu \mathrm{l}$ for acetamiprid and $2.2 \mathrm{ng} / \mu \mathrm{l}, 4.8 \mathrm{ng} / \mu \mathrm{l}, 10.65 \mathrm{ng} / \mu \mathrm{l}, 21.42 \mathrm{ng} / \mu \mathrm{l}, 51.52 \mathrm{ng} / \mu \mathrm{l}$, for cypermethrin, on the pronotum. The bees of the control received $1 \mu \mathrm{l}$ of sterilized water. After the inoculation, the bees were returned to their respective boxes and were carefully observed from the first minute to $24 \mathrm{~h}$ to monitor their behaviour and the mortality rate due to the toxicity.

\subsubsection{Administration Routes of Different Treatments: Indirect Route}

Before treatment, the bees remained unfed for 2 hours to induce a similar level of appetite. Then, bees were fed with $200 \mu \mathrm{l}$ of honey syrup with 5 increasing concentrations of acetamiprid $(4.8 \mathrm{ng} / \mu \mathrm{l}, 10.65 \mathrm{ng} / \mu \mathrm{l}, 21.42 \mathrm{ng} / \mu \mathrm{l}, 51.52 \mathrm{ng} / \mu \mathrm{l}$, $113.4 \mathrm{ng} / \mu \mathrm{l})$ and cypermethrin $(2.2 \mathrm{ng} / \mu \mathrm{l}, 4.8 \mathrm{ng} / \mu \mathrm{l}, 10.65 \mathrm{ng} / \mu \mathrm{l}, 21.42 \mathrm{ng} / \mu \mathrm{l}$, $51.52 \mathrm{ng} / \mu \mathrm{l})$ respectively dissolved in honey, for test treatments, and honey diluted with water for the control. The syrup consumption of $10 \mu \mathrm{L}$ per bee, the volume corresponding to the average consumption per bee, has been associated with consumption.

When the bees have finished the ingestion of the solution, the honey syrup was refilled and the bees renewed for the following dose. The contaminated food was provided to bees for 3 hours and then exchanged with uncontaminated food (hone syrup). The volume of contaminated syrup unconsumed by each group of bees was measured to confirm the approximate dose ingested by bees in each box.

The bees were observed as for the above mentioned protocol.

\subsubsection{Determination of Mortality Rates}

To determine the mortality of each bee, the mechanic stimuli were applied by touching the body of the bees upon each evaluation, using a thin paintbrush. Bees who did not respond to the stimuli were scored as dead.

The mortality rates of control and contaminated bees were calculated according to the methods described by [13].

\section{- Correction of the mortality rate}

The mortality ratio was corrected on control mortality with the following [15] formula:

$$
1-\left(\frac{T_{a}}{C_{a}}\right) \frac{C_{b}}{T_{b}}
$$

As the parameter comprised live individuals and uniform numbers of bees per treatment (test and control), the [16] formula was used to correct the resulting mortality: 


$$
\frac{C_{a}-T_{a}}{C_{a}}
$$

where $T_{b}=$ number of live bees before treatment, $T_{a}=$ number of live bees after treatment, $C_{b}=$ number of live bees in control before treatment, and $C_{a}=$ number of live bees in control after treatment.

\section{- LC50 lethal dose}

The procedures for the determination of the oral LC50 were based on [13] and [17] methods developed for $A$. mellifera. Lethal concentration 50 (LC50) is the dose leading to the death of $50 \%$ of individuals. This LC50 accounts for the intrinsic toxicity of the active substance in question. For the determination of this concentration, we proceed to a transformation into Probits of the percentages of corrected mortality, and the transformation into decimal logarithm of the concentration.

\subsubsection{Data Analysis}

Data on mortality were obtained from the bio-assays and thereafter subjected to statistical analysis using the Probit method [18] and $\mathrm{R}^{\circledast}$ software. LC50 values were determined, as well as their respective $95 \%$ confidence intervals values.

\section{Results}

\subsection{Distribution of Insecticides Sold on the Market According to Their Active Ingredients}

Figure 1 shows the distribution of insecticides according to the active ingredients sold in Ngaoundéré.

Of the 32 insecticides identified on markets and from farmers, $21.89 \%$ were made of cypermethrin and $18.25 \%$ acetamiprid. It can, therefore, be concluded that insecticides made of cypermethrin and acetamiprid are the most used in Ngaoundéré.

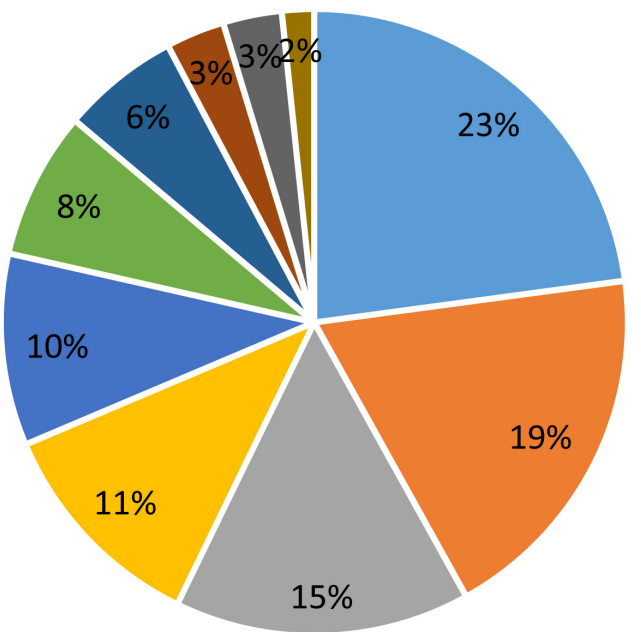

$$
\begin{aligned}
& \text { - Cypermethrin } \\
& \text { - Acetamiprid } \\
& \text { - Lambda+Cyhalothrin } \\
& \text { - Pyrimiphos-methyl } \\
& \text { - Chlorpyriphos } \\
& \text { - Chlorpyriphos }
\end{aligned}
$$

Figure 1. Distribution of insecticides sold in the market according to their active ingredients. 


\subsection{Observation of Symptoms Induced by Acetamiprid and Cypermethrin}

For the direct and indirect toxicity, bees were tested with increasing doses of acetamiprid and cypermethrin. Mortality was monitor after $1 \mathrm{~h}, 4 \mathrm{~h}$, and $24 \mathrm{~h}$. The symptoms observed on bees during intoxication through indirect contact (ingestion) and direct contact (topical application) of the different products are quickly manifested by the symptoms of neurotoxicity such as disordered and rapid movements, convulsions followed by tremors.

\subsection{Assessment of Acute Toxicity of Acetamiprid and Cypermethrin}

\subsubsection{Sensitivity by Direct Contact of Acetamiprid and Cypermethrin}

The results of direct toxicity are shown in Figure 2 and Figure 3. From this figure, it appears that the mortality increases with the concentration and the maximum mortality $(100 \%)$ is reached 4 hours through topical application at 113.4

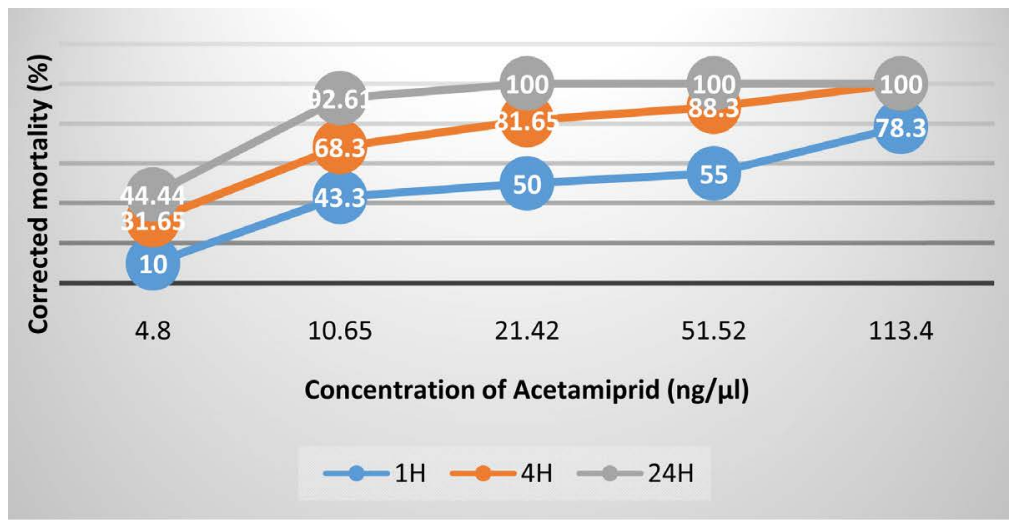

(A)

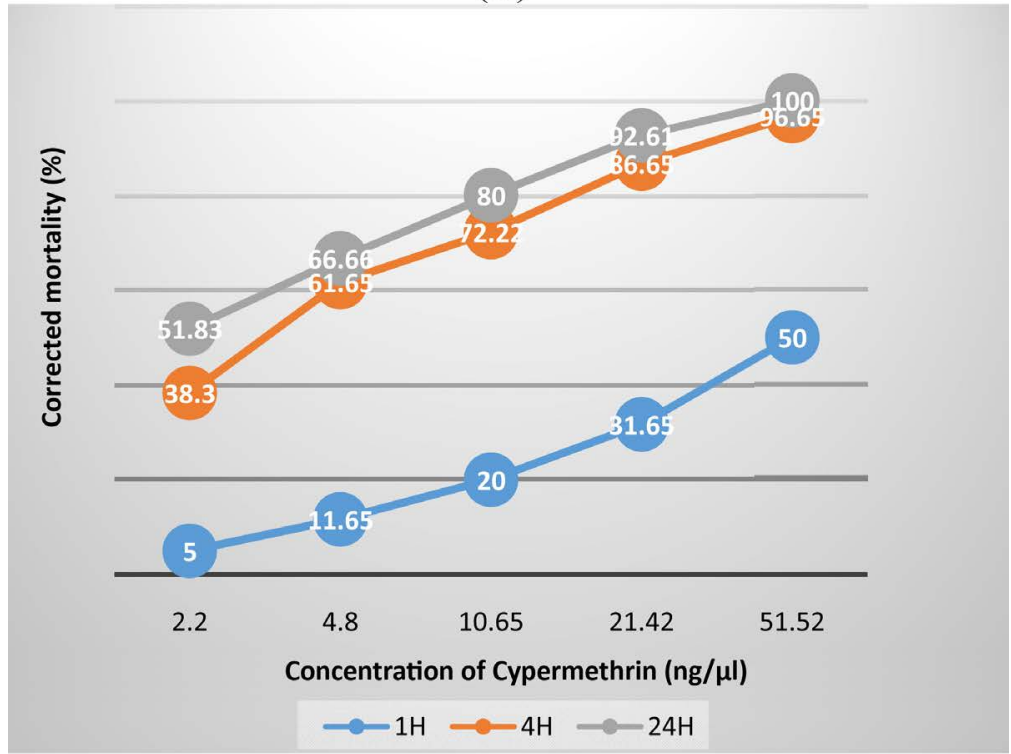

(B)

Figure 2. Concentration-mortality relationship after bees contact. (A) Acetamiprid; (B) Cypermethrin. 


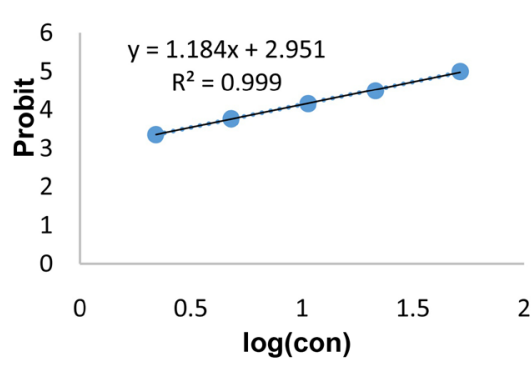

(A)

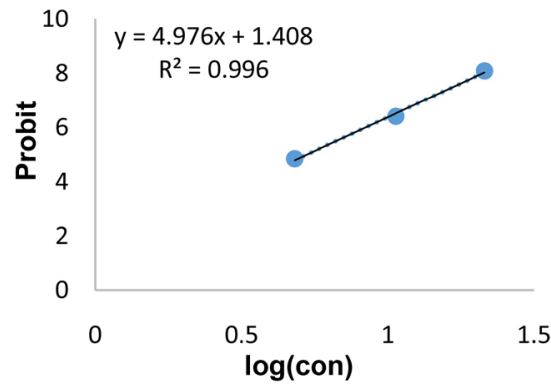

(C)

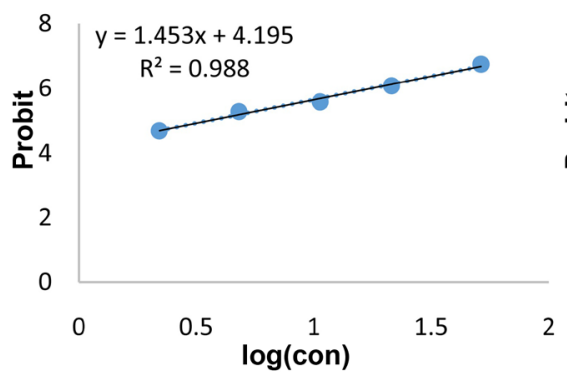

(E)

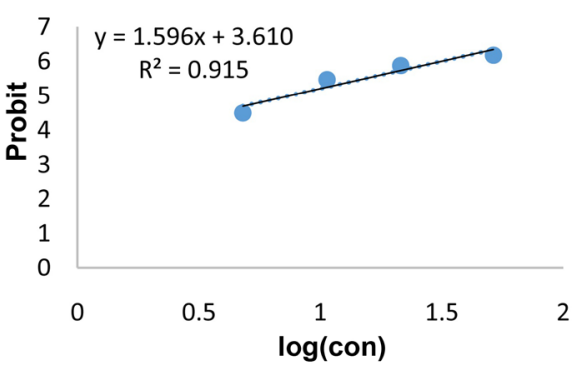

(B)

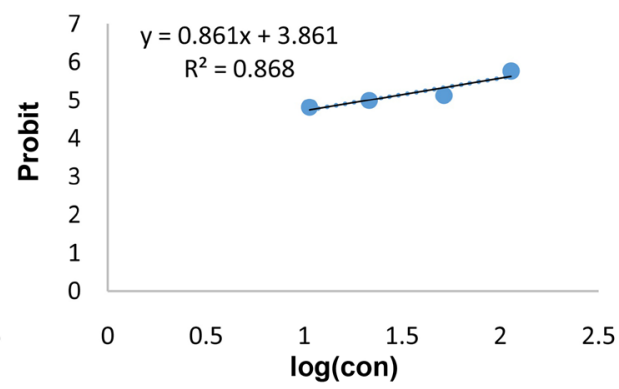

(D)

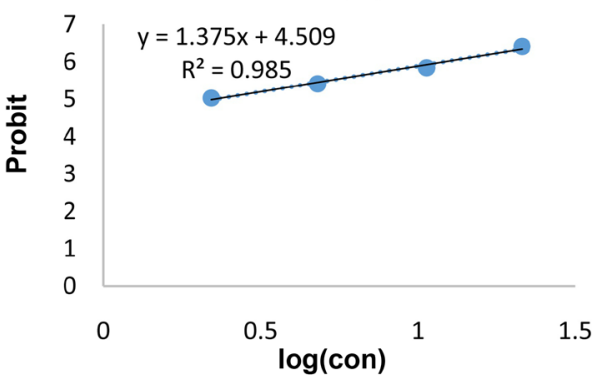

(F)

Figure 3. Regression line probit transformation of acetamiprid (A, B, C) and cypermethrin $(\mathrm{D}, \mathrm{E}, \mathrm{F})$ concentrations after $1(\mathrm{~A}$ and $\mathrm{D}), 4(\mathrm{~B}$ and $\mathrm{E})$ and $24(\mathrm{C}$ and $\mathrm{F})$ hours of direct contamination.

$\mathrm{ng} / \mu \mathrm{l}$ for acetamiprid while for cypermethrin it occurs after 24 hours at $51.52 \mathrm{ng} / \mu \mathrm{l}$. Besides, the lowest concentration of $4.8 \mathrm{ng} / \mu \mathrm{l}$ for acetamiprid and $2.2 \mathrm{ng} / \mu \mathrm{l}$ for cypermethrin induced the lowest mortality, $31.65 \%$, and $38.3 \%$ respectively.

From Figure 2, it also appears that the higher the concentration, the faster death occurs. The maximum is reached 4 hours after topical application of acetamiprid and 24 hours after that of cypermethrin, at $113.4 \mathrm{ng} / \mu \mathrm{l}$ for acetamiprid and $51.52 \mathrm{ng} / \mu \mathrm{l}$ for cypermethrin. These observations are similar to those obtained by [19] with thiamethoxam where the maximum is reached after 24 hours with $A$. m. intermissa.

\subsubsection{Sensitivity through Indirect Contact of Acetamiprid and Cypermethrin}

The results of indirect toxicity for the two insecticides are shown in Figure 4 and Figure 5.

From Figure 4, it appears that the mortality increases according to the administered concentration. Indeed, there is a directly proportional relationship between 


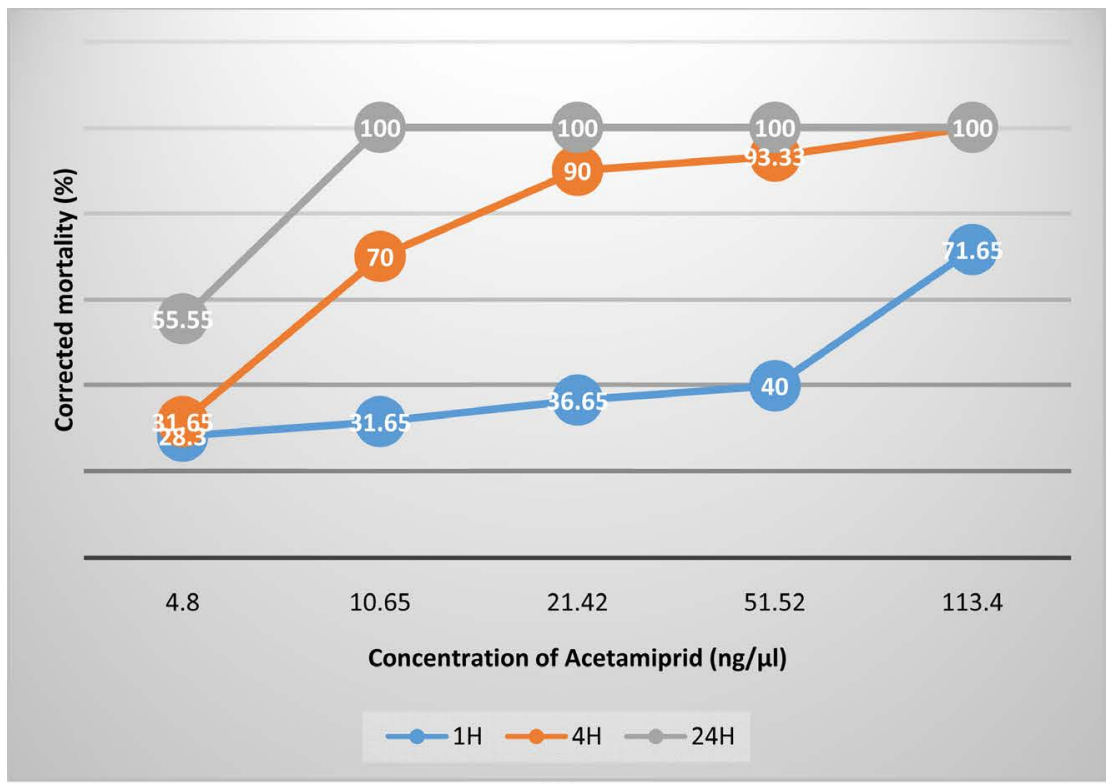

(A)

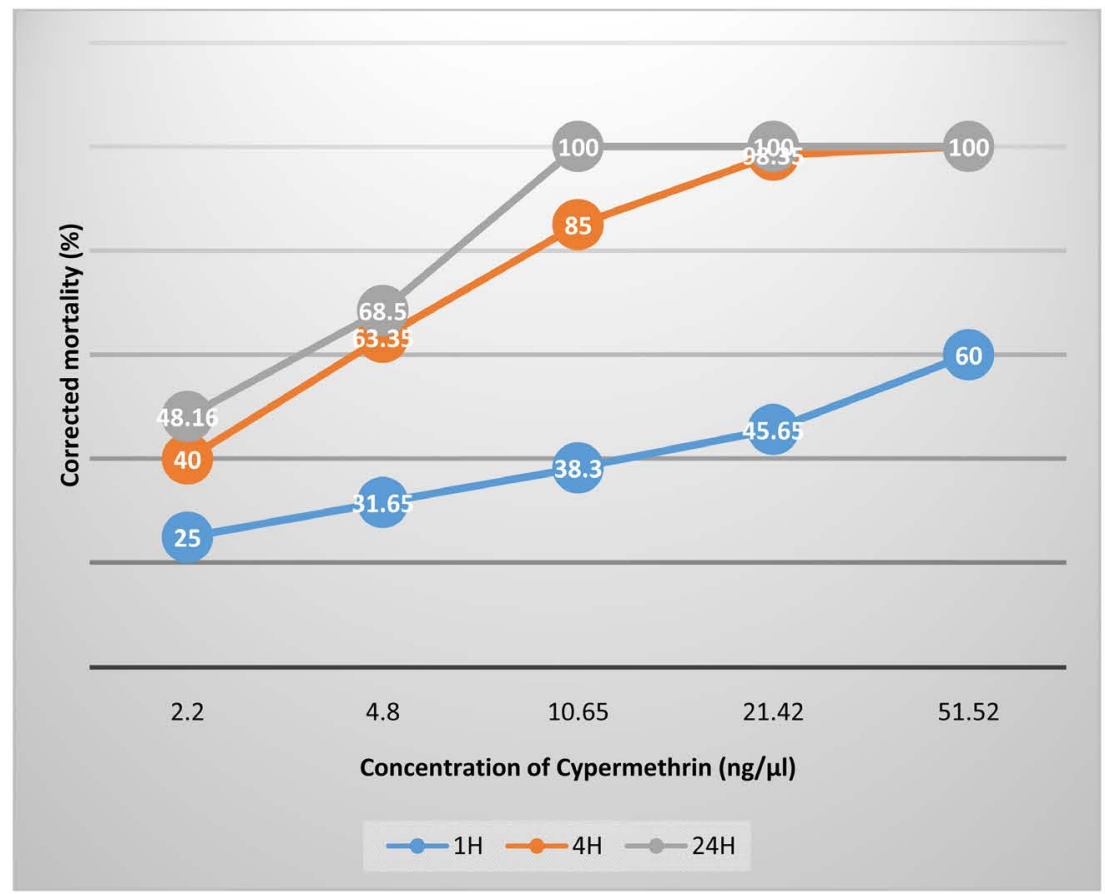

(B)

Figure 4. Concentration-mortality relationship after indirect contamination of bees. (A) Acetamiprid; (B) Cypermethrin.

the administered concentration and the observed mortality. The maximum mortality is reached after 4 hours through the ingestion of $113.4 \mathrm{ng} / \mu \mathrm{l}$ of acetamiprid, and for cypermethrin, it occurs at the same time but with $51.52 \mathrm{ng} / \mathrm{ul}$.

Thus, cypermethrin is more toxic than acetamiprid through indirect contact; this is justified by the difference between the active ingredients and its action in bees' organism. The same observations were done by [20] who found maximum mortality after 24 hours at $239.50 \mathrm{ng} /$ bee of deltamethrin. 


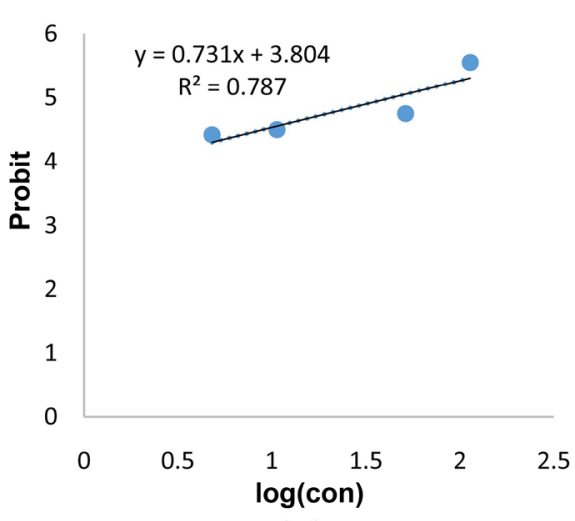

(A)

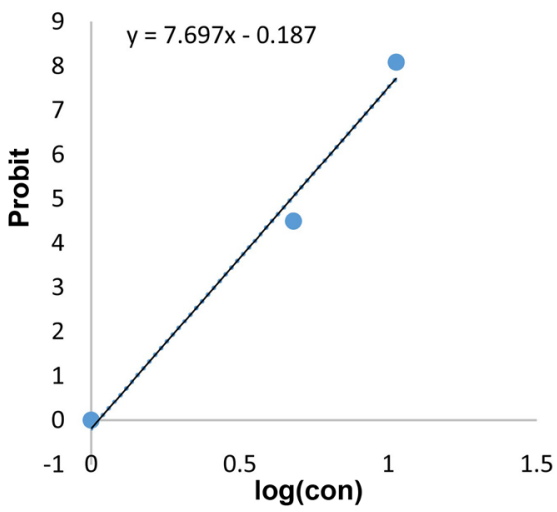

(C)

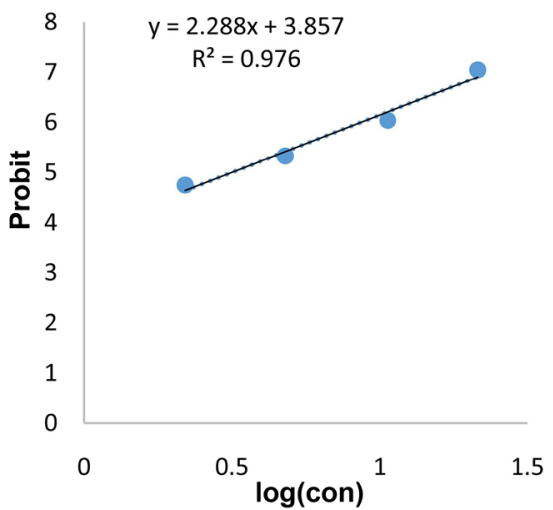

(E)

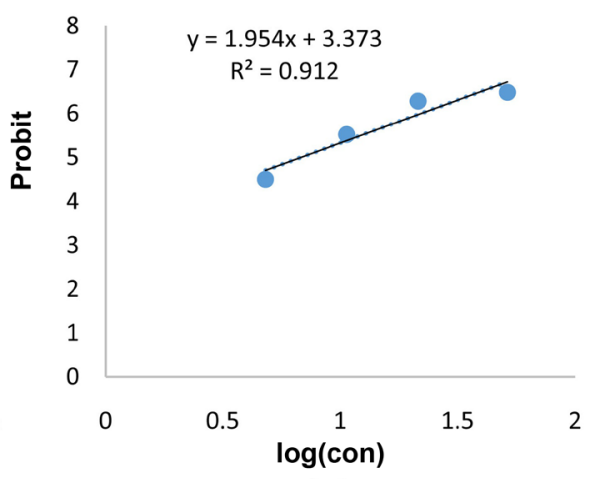

(B)

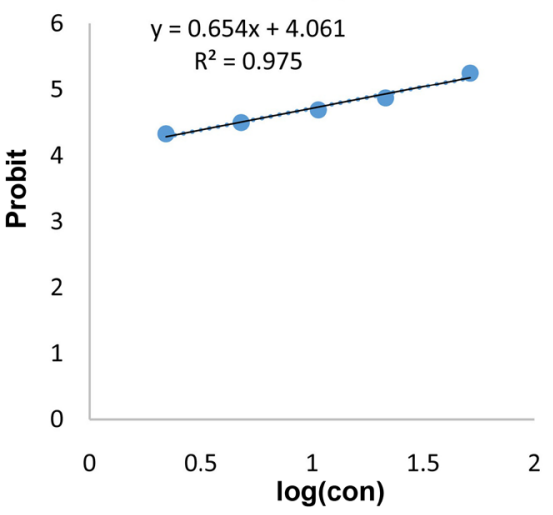

(D)

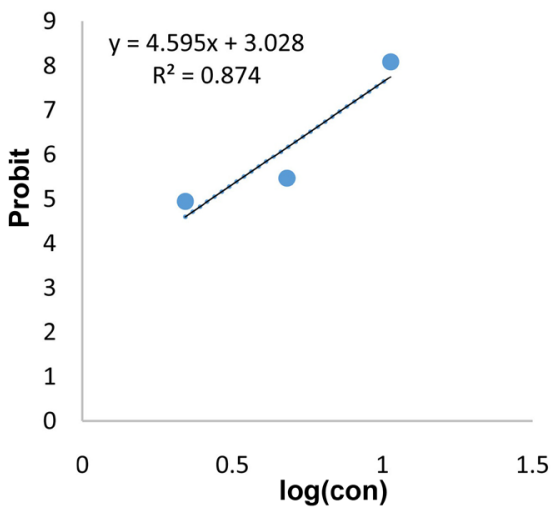

(F)

Figure 5. Regression line probit transformation of acetamiprid (A, B, C) and cypermethrin $(\mathrm{D}, \mathrm{E}, \mathrm{F})$ concentrations after 1 ( $\mathrm{A}$ and $\mathrm{D}), 4$ (B and E) and 24 (C and F) hours of indirect contamination (ingestion).

For acetamiprid, $100 \%$ mortality occurs after 4 hours at $113.4 \mathrm{ng} / \mu \mathrm{l}$ and for cypermethrin, it occurs after this same time but with $51.52 \mathrm{ng} / \mu \mathrm{l}$.

\subsection{Determination of Oral and Contact LC50 for Acetamiprid and Cypermethrin}

After topical application and ingestion of acetamiprid and cypermethrin, mortality is monitored between 0 minute and 24 hours. The LC50 values are determined from the regression lines (Figure 3 and Figure 5) obtained by probit 
transformations of the corrected percentages and the logarithmic transformation of the administered concentrations. The values are grouped in Table 1.

The LC50 values for acetamiprid obtained after $1 \mathrm{~h}, 4 \mathrm{~h}$, and $24 \mathrm{~h}$ were respectively $20.99 \mathrm{ng} / \mu \mathrm{l}, 7.41 \mathrm{ng} / \mu \mathrm{l}$, and $5.26 \mathrm{ng} / \mu \mathrm{l}$ for topical toxicity, and $43.19 \mathrm{ng} / \mu \mathrm{l}$, $6.79 \mathrm{ng} / \mu \mathrm{l}$, and $4.70 \mathrm{ng} / \mu \mathrm{l}$ orally. For the same times, the LC50 values for cypermethrin were $52.48 \mathrm{ng} / \mu \mathrm{l}, 3.57 \mathrm{ng} / \mu \mathrm{l}, 2.27 \mathrm{ng} / \mu \mathrm{l}$ for topical application and 27.27 $\mathrm{ng} / \mu \mathrm{l}, 15 \mathrm{ng} / \mu \mathrm{l}, 2.68 \mathrm{ng} / \mu \mathrm{l}$ for oral toxicity.

It can be seen from Table 1 that from 0 minute to 1 hour, the difference is highly significant for both insecticides, acetamiprid being more toxic through indirect contact (ingestion) and cypermethrin through direct contact (topical application). However, from the fourth hour to the $24^{\text {th }}$, there is no significant difference between the oral and topical LC50s of the two products at the 5\% level.

From Table 1, it also appears that the LC50 of acetamiprid is higher than that of cypermethrin by direct contact $7.41 \mathrm{ng} / \mu \mathrm{l}$ and $3.35 \mathrm{ng} / \mu \mathrm{l} ; 5.26 \mathrm{ng} / \mu \mathrm{l}$ and 2.27 $\mathrm{ng} / \mu \mathrm{l}$ respectively between 4 and 24 hours and by ingestion $6.79 \mathrm{ng} / \mu \mathrm{l}$ and 3.15 $\mathrm{ng} / \mu \mathrm{l} ; 4.70 \mathrm{ng} / \mu \mathrm{l}$ and $2.68 \mathrm{ng} / \mu \mathrm{l}$ respectively between 4 and 24 hours. Analysis of variance indicated a significant difference between acetamiprid and cypermethrin through contact and oral route after 4 and 24 hours at the 5\% level. This confirms that cypermethrin is more toxic than acetamiprid through contact and ingestion. The obtained values differ from those of [19] [20] [21].

\section{Discussion}

The results obtained from Figure 1 could be explained by the efficiency of these two agrochemical products, their availability in different villages, markets and shops and especially their cost. According to most of the interviewed farmers, these factors guide their choice and they are closely related to each other. Our results differ from those obtained by [22] who showed that in Benin, in the cotton zones, more precisely in Bimbèrèkè, treatments are carried out with deltamethrin, and the endosulfan. However, in the gardening areas deltamethrin and the mixture of cyfluthrin and malathion are the most commonly used insecticides.

On symptoms induced by acetamiprid and cypermethrin (through direct contact), our results are in line with those of [21] [23]. According to these authors, the same symptoms were induced by imidacloprid on Apis mellifera and A. m. causasica.

Table 1. LC50 for acetamiprid and cypermethrin in bees.

\begin{tabular}{ccccccc}
\hline \multicolumn{7}{c}{ CL50 (ng/ul/bee) } \\
\hline Acetamiprid & \multicolumn{3}{c}{ Cypermethrin } \\
\hline Time (Hours) & 1 & 4 & 24 & 1 & 4 & 24 \\
Direct contact & $20.99^{\mathrm{a}}$ & $7.41^{\mathrm{a}}$ & $5.26^{\mathrm{a}}$ & $52.48^{\mathrm{b}}$ & $3.57^{\mathrm{a}}$ & $2.27^{\mathrm{a}}$ \\
Indirect contact & $43.19^{\mathrm{b}}$ & $6.79^{\mathrm{a}}$ & $4.70^{\mathrm{a}}$ & $27.27^{\mathrm{a}}$ & $3.15^{\mathrm{a}}$ & $2.68^{\mathrm{a}}$ \\
\hline
\end{tabular}

Within the same column, figures with the same letter are not significantly different. 
Moreover, for [24] and [25], some insecticides act as neurotoxic agents and affect the mobility of bees by inducing symptoms such as tremors, incoordination of movements and hyperactivity.

It is also noted that the occurrence of the first cases of mortality is observed for acetamiprid 15 minutes after the ingestion of the highest concentration (113.4 $\mathrm{ng} / \mu \mathrm{l})$ and 30 minutes after the inoculation of the insecticide through contact.

For the acute Toxicity of Acetamiprid and Cypermethrin on honeybees (Figure 2 and Figure 3), our results are in line with those of [19] who found the same mortality (100\%) with thiamethoxam with $26.01 \mathrm{ng} / \mathrm{ab}$ after 24 hours with A. m. intermissa. [26] obtained $100 \%$ of mortality at $290 \mathrm{ng} / \mu \mathrm{l}$ after 24 hours with thunder. Therefore, the difference in sensitivity of bees could be related to 1) the speed of action of the products, 2) the agrochemical products and 3) the physiology of each sub-species as it varies from one sub-species to another.

The analysis of the variance reveals that $\mathrm{p}$ value of $F$-test is less than 0.05 , there is therefore, a significant difference between the means. Furthermore, there is a strong relationship between acetamiprid and cypermethrin administered through direct route (topical application) and the observed mortality.

On symptoms induced by acetamiprid and cypermethrin through indirect contact (Figure 4 and Figure 5), The same results have been highlighted by [19] with thiamethoxam, where the maximum mortality occurred after 24 hours with doses between 30 and $100 \mathrm{ng} / \mathrm{bee}$ with $A$. m. intermissa and between 20 and 50 ng/bee for $A$. m. sahariensis.

The analysis of the variance reveals that the value of the $F$-test is less than 0.05 , there is therefore, a significant difference between the means. Furthermore, there is a strong relationship between the dose of acetamiprid and cypermethrin administered through ingestion and the observed mortality.

For the LC50 for acetamiprid and cypermethrin, our results differ from those of [21] who found that imidacloprid is more toxic orally than topically and [19] with thiamethoxam found a value of $12.29 \mathrm{ng} / \mathrm{bee}$ orally and $26.01 \mathrm{ng} / \mathrm{bee}$ through contact with A. m. intermissa after 24 hours. Also, [20] reports a LD50 value of $109.72 \mathrm{ng} /$ bee through topical application and $239.50 \mathrm{ng} / \mathrm{bee}$ through ingestion with deltamethrin. Similarly, the toxicity of organophosphates, such as chlorpyrifos, appears 4 times higher through direct contact than oral route [27]. To explain this difference, Gilbert and Wilkinson (1975) quoted by [20] reported that the ingested product passes into the detoxification organs, intestine and Malpighi tubes, before being distributed throughout the body. On the other hand, the product applied to the thorax passes through the cuticle through waxy tubules and the distribution takes place directly in the body, more particularly in the most lipophilic zones.

Our results on LC50 confirm that cypermethrin is more toxic than acetamiprid through contact and ingestion. The obtained values differ from those of [19] [20] [21] [24]. This variability of toxicity can be related to the active ingredients used and these active ingredients vary according to the mode of applica- 
tion, the experimental conditions (temperature, relative humidity), the experimental parameters (number of bees in each batch), the number of repetitions [20] and physiology of the subspecies used as a biological organism. However, according to the toxicological classification of [28], pesticides whose LD50 is less than $2 \mu \mathrm{g} /$ bee are highly toxic to $A$. mellifera.

\section{Conclusion}

Results demonstrated that acetamiprid and cypermethrin are toxic to A. mellifera. Similarly, in A. mellifera, there is a directly strong relationship between the administered concentration of acetamiprid and cypermethrin and the observed mortality; and between mortality and time. Furthermore, the study found that acetamiprid and cypermethrin are toxic to honeybees and there was no significant difference between topical and oral toxicity, 24 hours later. Besides, both insecticides are toxic after the first hour and acetamiprid is more toxic than cypermethrin through direct contact and ingestion from the $4^{\text {th }}$ to the $24^{\text {th }}$ hours. These results confirm the danger associated with these insecticides used during the flowering period of the cultivated plants. The application of these chemicals in the agricultural area will be leading to the death of bees and other pollinators useful for agriculture and beekeeping. Considering all these risks, it is, therefore, essential to set up monitoring, warning and awareness mechanisms on the use of insecticides in agricultural areas and to educate farmers.

\section{Acknowledgements}

We would like to be grateful to the University of Ngaoundéré, the Faculty of Science and the Laboratory of Applied Zoology for allowing to conduct this research.

This research did not receive any specific grant from funding agencies in the public, commercial, or not-for-profit sectors.

\section{Conflicts of Interest}

The authors declare no conflicts of interest regarding the publication of this paper.

\section{References}

[1] Dainese, M., Martin, E.A., Aizen, M.A., Albrecht, M., Bartomeus, I., Bommarco, R., Carvalheiro, L.G., Chaplin-Kramer, R., Gagic, V., Garibaldi, L.A., Ghazoul, J., Grab, H., Jonsson, M., Karp, D.S., Kennedy, C.M., Kleijn, D., Kremen, C., Landis, D.A., Letourneau, D.K., Marini, L., Poveda, K., Rader, R., Smith, H.G., Tscharntke, T., Andersson, G.K.S., Badenhausser, I., Baensch, S., Bezerra, A.D.M., Bianchi, F.J.J.A., Boreux, V., Bretagnolle, V., Caballero-Lopez, B., Cavigliasso, P., Ćetković, A., Chacoff, N.P., Classen, a., Cusser, S., da Silva e Silva, F.D., de Groot, G.A., Dudenhöffer, J.H., Ekroos, J., Fijen, T., Franck, P., Freitas, B.M., Garratt, M.P.D., Gratton, C., Hipólito, J., Holzschuh, A., Hunt, L., Iverson, A.L., Jha, S., Keasar, Kim, T.T.N., Kishinevsky, M., Klatt, B.K., Klein, A.M., Krewenka, K.M., Krishnan, S., Larsen, A.E., Lavigne, C., Liere, H., Maas, B., Mallinger, R.E., Pachon, E.M., Martínez-Salinas, A., 
Meehan, T.D., Mitchell, M.G.E., Molina, G.A.R., Nesper, M., Nilsson, L., O'Rourke, M.E., Peters, M.K., Plećaš, M., Potts, S.G., Ramos, D.L., Rosenheim, J.A., Rundlöf, M., Rusch, A., Sáez, A., Scheper, J., Schleuning, M., Schmack, J.M., Sciligo, A.R., Seymour, C., Stanley, D.A., Stewart, R., Stout, J.C., Sutter, L., Takada, M.B., Taki, H., Tamburini, G., Tschumi, M., Viana, B.F., Westphal, C., Willcox, B.K., Wratten, S.D., Yoshioka, A., Zaragoza-Trello, C., Zhang, W., Zou, Y. and Steffan-Dewenter, I. (2019) A Global Synthesis Reveals Biodiversity-Mediated Benefits for Crop Production. Science Advances, 5, 1-13. https://doi.org/10.1126/sciadv.aax0121

[2] Potts, S.G., Imperatriz-Fonseca, V., Ngo, H.T., Aizen, M.A., Biesmeijer, J.C., Breeze, T.D., Dicks, L.V., Garibaldi, L.A., Hill, R., Settele, J. and Vanbergen, A.J. (2016) Safeguarding Pollinators and Their Values to Human Well-Being. Nature, 1, 1-10. https://doi.org/10.1038/nature20588

[3] Klein, A.M., Vaissière, B.E., CANE, J.H., Steffan-Dewenter, I., Cunningham, S.A. Kremen, C. and Tscharntke, T. (2007) Importance of Pollinators in Changing Landscapes for World Crops. Proceedings of the Royal Society, London (B), 274, 303-313. https://doi.org/10.1098/rspb.2006.3721

[4] Patrício-Roberto, G.B., Maria, J.O. and Campos, M.J.O. (2014) Aspects of Landscape and Pollinatorswhat Is Important to Bee Conservation. Diversity, 6, 158-175. https://doi.org/10.3390/d6010158

[5] Roubik, D.W. (1995) Pollination of Cultivated Plants in the Tropics. FAO Agricultural Services Bulletin, 12, 188-198

[6] Winfree, R., Reilly, J.R., Bartomeus, I., Cariveau, D.P., Williams, N.M. and Gibbs, J. (2018) Effects of Sublethal Doses of Acetamiprid and Thiamethoxam on the Behavior of the Honeybee (Apis mellifera). Science, 359, 791-793. https://doi.org/10.1126/science.aao2117

[7] Belzunces, L.P., Tchamitchian, S. and Brunet, J.L. (2012) Neural Effects of Insecticides in the Honey Bee. Apidologie, 43, 348-370.

https://doi.org/10.1007/s13592-012-0134-0

[8] Pisa, L., Amaral-Rogers, V., Belzunces, L.P., Bonmatin, J.M., Downs, C., Goulson, D., Kreutzweiser, D.P., Krupke, C., Liess, M., McField, M., Noome, D.A., Settele, J., Simon-Delso, N., Stark, J.D., Van der Sluijs, J.P., Van Dyck, H. and Wiemers, M. (2014) Effects of Neonicotinoids and Fipronil on Non-Target Invertebrates. Environmental Science and Pollution Research, 22, 68-102.

[9] Badawy, M.E.I., Hoda, M.N. and Entsar, I.R. (2015) Toxicity and Biochemical Changes in the Honeybee Apismellifera Exposed to Four Insecticides under Laboratory Conditions. Apidologie, 46, 177-193. https://doi.org/10.1007/s13592-014-0315-0

[10] (1998) OECD Guidelines for the Testing of Chemicals, Section 2, Effects on Bioticsystems. Honeybees, Acute Oral Toxicity Test, N. 213, 8 p.

[11] Miranda, J.E., Navickiene, H.M.D., Nogueira-Couto, R.H., DeBortoli, S.A., Kato, M.J., Bolzani, V.S. and Furlan, M. (2003) Susceptibility of Apis mellifera (Hymenoptera: Apidae) to Pellitorine, an Amide Isolated from Piper tuberculatum (Piperaceae). Apidologie, 34, 409-415. https://doi.org/10.1051/apido:2003036

[12] CEB (1995) Méthode de laboratoired' évaluation des effets de toxicitéaigüeorale et decontact des préparationsphytopharmaceutiques chez l'abeille domestique Apis mellifera L. Méthode, No. 95, 8 p.

[13] Medrzycki, P., Giffard, H., Aupinel, P., Belzunces, L.P., Chauzat, M.P., Claßen, C., Colin, M.E., Dupont, T., Girolami, V., Johnson, R., Le Conte, Y., Lückmann, J., Marzaro, M., Pistorius, J., Porrini, C., Schur, A., Sgolastra, F., Delso, N.S., van der 
Steen, J.J.M., Wallner, K., Alaux, C., Biron, D.G., Blot, N., Bogo, G., Brunet, J.L., Delbac, F., Diogon, M., El Alaoui, H., Provost, B., Tosi, S. and Vidau, C. (2013) Standard Methods for Toxicology Research in Apismellifera. Journal of Apicultural Research, 52, 1-60. https://doi.org/10.3896/IBRA.1.52.4.14

[14] Decourtye, A. and Devillers, J. (2010) Ecotoxicity of Neonicotinoid Insecticides to Bees. In: Thany, S.H., Ed., Insect Nicotinic Acetylcholine Receptors, Springer, New York, 85-95. https://doi.org/10.1007/978-1-4419-6445-8_8

[15] Henderson, C.F. and Tilton, E.W. (1955) Tests with Acaricides against the Brow Wheat Mite. Journal of Economic Entomology, 48, 157-161. https://doi.org/10.1093/jee/48.2.157

[16] Abbott, W.S. (1925) A Method of Computing the Effectiveness of an Insecticide. Journal of Economic Entomology, 18, 265-267.

https://doi.org/10.1093/jee/18.2.265a

[17] (1998) OECD Guidelines for the Testing of Chemicals, Section 2, Effects on Bioticsystems. Honeybees, Acute Oral Toxicity Test, No. 214, 7 p.

[18] Finney, D.J. (1971) Probit Analysis. 3rd Edition, Cambridge University Press, Cambridge, 318 .

[19] Nora, C., Mohamed, C. and Salaheddine, D. (2014) Evaluation of Acute Toxicity of Thiamethoxam in Algerian Honeybee Apis mellifera Apis melliferaintermissa, Apis mellifera sahariensis. International Journal of Zoology and Research, 4, 29-40.

[20] Rafalimanana, H.J. (2003) Evaluation des effetsd'insecticides sur deux typesd'Hyménoptèresauxiliaires des cultures, l'abeille domestique (Apis mellifera L.) etdesparasitoïdes de pucerons: Études de terrain à Madagascar et de laboratoireenFrance.

[21] Suchail, S., Guez, D. and Belzunces, L. (2000) Characteristics of Imidacloprid Toxicity in Two Apismellifera Subspecies. Environmental Toxicology and Chemistry, 19, 1901-1905. https://doi.org/10.1002/etc.5620190726

[22] Akogbeto, M.C., Djouaka, R. and Noukpo, H. (2005) Use of Agricultural Insecticides in Benin. Bulletin de la Societe de Pathologie Exotique, 98, 400-405.

[23] Suchail, S., Belzunces, L.P. and Vaissiere, B.E. (2003) Toxicitéaigue de l'imidaclopride et desesmétabolites chez l'abeille domestique Apis mellifera. Abeilles et Fleurs, 643, 27-30.

[24] Lambin, M., Armengaud, C., Raymond, S. and Gauthier, M. (2001) Imidacloprid-Induced Facilitation of the Proboscis Extension Reflex Habituation in the Honeybee. Archives of Insect Biochemistry and Physiology, 48, 129-134. https://doi.org/10.1002/arch.1065

[25] Nauen, R., Ebbinghaus-Kintscher, U. and Schmuck, R. (2001) Toxicity and Nicotinic Cetylcholine Receptor Interaction of Imidacloprid and Its Metabolites in Apis mellifera (Hymenoptera: Apidae). Pest Management Science, 57, 577-586. https://doi.org/10.1002/ps.331

[26] Suchail, S., Guez, D. and Belzunces, L.P. (2001) Discrepancy between Acute and Chronic Toxicity Induced by Imidacloprid and Its Metabolites in Apis mellifera. Environmental Toxicology and Chemistry, 20, 2482-2486. https://doi.org/10.1002/etc.5620201113

[27] Mishra, R.C. and Verma, A.K. (1982) Relative Toxicity of Some Insecticides to Apis cerana indica F. Workers. Indian Bee Journal, 44, 69-71.

[28] Johansen, C.A. and Mayer, D.F. (1990) Pollinator Protection: A Bee and Pesticide Handbook. Wicwas Press, Cheshire, 212 p. 